Volume 13

\title{
The Complicated Cases of Soghomon Tehlirian and Sholem Schwartzbard and Their Influences on Raphaël Lemkin's Thinking About Genocide
}

Steven Leonard Jacobs

The University of Alabama

Follow this and additional works at: https://digitalcommons.usf.edu/gsp

\section{Recommended Citation}

Jacobs, Steven Leonard (2019) "The Complicated Cases of Soghomon Tehlirian and Sholem Schwartzbard and Their Influences on Raphaël Lemkin's Thinking About Genocide," Genocide Studies and Prevention: An International Journal: Vol. 13: Iss. 1: 33-41.

DOI:

https://doi.org/10.5038/1911-9933.13.1.1594

Available at: https://digitalcommons.usf.edu/gsp/vol13/iss1/7

This Articles is brought to you for free and open access by the Open Access Journals at Digital Commons @ University of South Florida. It has been accepted for inclusion in Genocide Studies and Prevention: An International Journal by an authorized editor of Digital Commons @ University of South Florida. For more information, please contact digitalcommons@usf.edu. 


\title{
The Complicated Cases of Soghomon Tehlirian and Sholem Schwartzbard and Their Influences on Raphaël Lemkin's Thinking About Genocide
}

\author{
Steven Leonard Jacobs \\ The University of Alabama \\ Tuscaloosa, Alabama, USA
}

\section{Introduction}

In 1955, four years before his death on August 24, 1959, of a massive heart attack in his publicist Milton H. Blow's office in New York City, Raphaël Lemkin (1900-1959) finished his somewhat sanitized autobiography Totally Unofficial Man, ${ }^{1}$ an ironic indirect tribute to his lack of governmental and/or diplomatic status and credentials, but his nonetheless herculean effort to persuade forty-one member-states of the United Nations to sign the Convention on the Prevention and Punishment of the Crime of Genocide as presented to the General Assembly on December 9, 1948. ${ }^{2}$ Ratification would come later in 1951, including the United States under President Ronald Regan [1911-2004] November 5, 1988. That edited autobiography, with notes and commentary, would not be published until $2013,{ }^{3}$ however, although a lengthy excerpt had already been published somewhat earlier. ${ }^{4}$

In Totally Unofficial Man, and referring to his student days at Lvov University, Ukraine, and shortly after receiving his Doctor of Law degree, he references the trials of both Soghomon Tehlirian (1896-1960) and Sholem-Shmuel (Samuel) Schwartzbard (1886-1938) within the same two pages: ${ }^{5}$

The court in Berlin acquitted Tehlirian. It had decided that he had acted under 'psychological compulsion.' Tehlirian, who upheld the moral order of mankind, was classified as insane, incapable of discerning the moral nature of his act. He had acted as the self-appointed legal officer for the conscience of mankind. But can a man appoint himself to mete our justice? Will not passion sway such a form of justice and make a travesty of it? At that moment, my worries about the murder of the innocent became more meaningful to me. I didn't know all the answers, but I felt that a law against this type of racial or religious murder must be adopted by the world

At Lwow University, where I enrolled for the study of law, I discussed this matter with my professors. They evoked the argument about sovereignty of states. 'But sovereignty of states,' I answered, 'implies conducting an independent foreign and internal policy, building of schools, construction of roads, in brief, all types of activity directed toward the welfare of people.' 'Sovereignty,' I argued, 'cannot be conceived as the right to kill millions of innocent people.'

In 1926, after obtaining my Doctor of Law, another bomb exploded. In a rare moment of clarity that seething indignation instills, I further understood the concept of the crime I was trying to establish. In Paris, Shalom Schwartzbard ...shot the Ukrainian minister of war,

${ }^{1}$ At times, James Loeffler is highly critical of the way Lemkin chose to present himself, most especially "erasing" his Jewish-Zionist connections after coming to the United States in 1941. James Loeffler, "Becoming Cleopatra: the forgotten Zionism of Raphaël Lemkin," Journal of Genocide Research 19, no. 3 (2017), 340-360. For an interesting insight into Jewish autobiographical writing throughout history, see Michael Stanislawski, Autobiographical Jews: Essays in Jewish Self-Fashioning (Seattle and London: University of Washington Press, 2004).

${ }^{2}$ Australia (11 December), Belarus (16 December 1949), Bolivia (11 December), Bosnia \& Herzegovina (11 December), Brazil (11 December), Canada (28 November 1949), Chile (11 December), China (20 July 1949), Columbia (12 August 1949), Iceland (14 May 1949), India (29 November 1949), Iran (8 December 1949), Israel (17 August 1949), Lebanon (30 December 1949), Liberia (11 December), Mexico (14 December), Myanmar (30 December 1949), New Zealand (25 November 1949), Norway (11 December), Pakistan (11 December), United States (11 December), Uruguay (11 December).

${ }^{3}$ Raphaël Lemkin, Totally Unofficial: The Autobiography of Raphaël Lemkin, ed. Donna-Lee Frieze (New Haven and London: Yale University Press, 2013).

${ }^{4}$ Raphaël Lemkin, "Totally Unofficial Man” in Pioneers of Genocide Studies, ed. Samuel Totten, and Steven Leonard Jacobs (New Brunswick and London: Transaction Publishers, 2002), 365-399.

${ }^{5}$ He makes no further reference to either except an article which he does not cite on Schwartzbard, referring to the deed as a "beautiful crime" and that of Tehlirian as "upholding the moral order of mankind." 
Symon Petliura...The Paris jury found itself in the same moral dilemma as the court in Berlin. They could neither acquit Schwartzbard nor condemn him...but neither could it sanction the taking of the law in one's hands in order to uphold the moral standards of mankind...

Gradually, the decision was maturing in me that I had to act. ${ }^{6}$

To the degree that Lemkin's memories of those days and those trials are seemingly accurate, however, he seems to have accepted whatever materials were at his disposal then-but not subsequently-primarily newspapers in the languages with which he was familiar (e.g. Polish, French, German, Yiddish). As he continued his intellectual and legal conceptualizations evolving into genocide, he makes little to no further reference to these two cases. Thus, they were seemingly foundational to his past, but apparently not to his present nor his future work.

Further compounding the initial irony noted above are three significant omissions: (1) he makes no references whatsoever to the case of Herschel (Feibel) Grynszpan (1921 - 1944/45?) who shot the Third Secretary to the German/Nazi Embassy in Paris, Ernst Eduard vom Rath (1909-1938), on November 9, 1938, immediately prior to the destructive events of Kristallnacht (November 9-10, 1938) throughout Germany, and seemingly resulting from the subsequent deportation of Polish Jews, including his parents Sendel (who would survive the Holocaust, immigrate to Israel, and testify at the trial of Adolf Eichmann [1906-1962] in 1961) and Riva and his sister Berta, as well as 15,000 others, an event which served the Nazis well as a false prelude to the Holocaust/Shoah, events with which Lemkin was also no doubt intimately familiar; ; (2) subsequent research has further revealed information about both Tehlirian and Schwartbart, their associations, and their deeds, and thus calls into question not only the myths surrounding them and those same deeds, but their own biographies as well; (3) finally, Lemkin makes no mention whatsoever of the murder of Swiss Nazi leader Wilhelm Gustloff (1895-1936) by the Jewish medical student David Frankfurter (1909-1982), most obviously, perhaps, because, unlike Tehlirian and Schwartzbard, he was found guilty, sentenced to an eighteen-year prison term and expulsion. (Frankfurter served his sentence until 1945 when he was granted a pardon; left for pre-state Palestine/Israel where he later died.) Equally omitted from Lemkin's writing was the 1923 assassination by Maurice Conradi (18961947), a White Russian military man most of whose family was either murdered or executed by the Bolsheviks, who murdered Vatslav Vorovsky (1871-1923) and wounded two others-Ivan Ariens and Maxim Divilkovsky - in Geneva to attend the Lausanne Conference in 1923 in the aftermath of the First World War, an event which the Soviet government labeled the work of "White fascists." Conradi pled not guilty and was acquitted.

What, perhaps, is even more surprising is that, in his own articulations of these two political assassinations, evidently formative in his initial thinking about genocide, he does not even address even later, even in broad brushstrokes, the reality of the previous century when such acts were alltoo-common and all-too-well-known. As Eric Bogosian notes:

\footnotetext{
${ }^{6}$ Lemkin, Totally Unofficial Man, 20-21. Emphasis added.

${ }^{7}$ There are any number of texts which address the Grynszpan case. Most of them contain little to no material regarding these three cases, other than passing mentions. See, for example: Jonathan Kirsch, The Short, Strange Life of Herschel Grynszpan: A Boy Avenger, a Nazi Diplomat, and a Murder in Paris (New York: Liveright, 2013); Lionel Kochan, Pogrom: November 10, 1938 (London: Andre Deutsch, 1957); Konrad Heiden, The New Inquisition, trans. Heinz Norden (New York: The Starling Press, 1939); G. Warburg, Six Year of Hitler: The Jews Under the Nazi Regime (London: George Allen \& Unwin, 1939); Anthony Reed and David Fisher, Kristallnacht: The Nazi Night of Terror (New York: Random House, 1989); Colin McCullough and Nathan Wilson, eds., Violence, Memory, and History: Western Perceptions of Kristallnacht (London and New York: Routledge, 2015); Martin Gilbert, Kristallnacht: Prelude to Destruction (New York and London: Harper, 2006); Walter H. Pehle, ed., November 1938: From 'Kristallnacht' to Genocide (New York and Oxford: Berg, 1991); Mitchell G. Bard, 48 Hours of Kristallnacht: Night of Destruction/Dawn of the Holocaust: An Oral History (Guilford: The Lyons Press, 2008); Uta Gerhardt and Thomas Karlauf, eds., The Night of Broken Glass: Eyewitness Accounts of Kristallnacht (Cambridge, UK and Malden: Polity, 2012); Peter Broner: Night of the Broken Glass - A Novel (New York: Station Hill, 1991); Andy Marino, Herschel: The Boy Who Started World War II (Boston and London: Faber and Faber, 1995); Alan E. Steinweis, Kristallnacht 1938 (Cambridge, MA and London: Harvard University Press, 2009); Maria Mazzenga, ed., American Religious Responses to Kristallnacht (New York: Palgrave Macmillan 2009); Gerald Schwab, The Day the Holocaust Began: The Odyssey of Herschel Grynszpan (New York and London: Prager, 1990); Ruth Levitt, ed., Pogrom 1938: Prelude to the Holocaust: Testimonies from 'Kristallnacht' (London: Souvenir Press, 2015).
} 
The half-century prior to World War I was open season on world leaders. Three American presidents [Abraham] Lincoln (1809-1865), [James] Garfield (1831-1881), and [William] McKinley (1842-1901) were shot to death by assassins. A bullet would end the lives of Minister Juan Prim of Spain (1814-1870), King Umberto [I] of Italy (1844-1900), King Carlos of Portugal (1863-1908), King George [I] of Greece (1845-1913), and Naser al-Din Shah Quajar of Persia (1831-1976), Empress Elizabeth of Austria (1837-1898), President Sadi Carnot of France (1837-1894) and Richard Southwell Bourke, sixth Earl of Mayo (1822-1872), were stabbed to death. Gabriel Garcia Moreno (1821-1875), president of Ecuador, was hacked to death by machete. The killing spree against world leaders reached its climax in 1914, when Archduke Franz Ferdinand (1863-1914) of Austro-Hungary was gunned down by Gavrilo Princip (1894-1918), a Serbian nationalist, triggering World War I. ${ }^{8}$

\section{The Complicated Case of Soghomon Tehlirian}

This much is clear and was so to Lemkin as well and covered in the regular presses of Europe: Tehlirian was born on April 2, 1896 in the Turkish vilayet of Erzurum in the Ottoman Empire, when relations between other Turks and Armenians was already pre-genocidal under the failing regime of Sultan Abdul Hamid II (1842-1918; reigned 1876-1909) who would later be deposed by the Committee of Union and Progress (CUP). By the end of the Armenian Genocide (1915-1923), as could only be partially brought out due to the lack of data in his two-day trial in Berlin on June 2-3, 1921, approximately eighty-five members of his family would be murdered, including according to Tehlirian and his three lawyers, his mother, three sisters, one brother-in-law, two brothers, and a two-year-old niece; he himself having survived due to his mother's shielding him with her body and falling over him. On the morning of March 15, 1921, Tehlirian shot and killed Grand Vizier Mehmed Talaat Pasha (1874-1921), the prime architect of the genocide itself, and someone whose contempt for the Armenians was already communicated to US Ambassador to Turkey Henry Morgenthau, Sr. (1856-1946) who recorded their conversations in his Ambassador Morgenthau's Story, especially in Chapter 25, “Talaat Tells Why He 'Deports' the Armenians'." 9

Tehlirian did not deny his deed but did not consider himself a murderer, but, rather, someone who had avenged the murders of his family and his people. His three attorneys-Adolf von Gordon, Johannes Werthauer, and Kurt Niemeyer-took great care to present him as someone deeply troubled, burdened by great traumas and unbearable stresses-early indications of PostTraumatic Stress Disorder (PTSD), though the term itself was not yet in existence-and he was examined by several psychiatric medical professionals who testified regarding his mental state and difficulties and which certainly worked to Tehlirian's advantage in his overall defense. He presented himself in a relatively composed and humble manner, but made it a point to relate a dream in which his mother told him, "You saw Talaat and you did not avenge your mother's, father's brothers' and sisters' murders? You are no longer my son."10

The jury consisted of twelve men - a mason, a merchant, a jeweler, two landlords, a roofer, two locksmiths, a painter, a pharmacist, a painter, and an executive-who deliberated for a little more than one hour, and responded to the judge's question, "Is the defendant, Soghomon Tehlirian, guilty of having intentionally killed a man, Talaat Pasha, on March 15, 1921, in Charlottenburg?" The foreman answered, "No!"

The Presiding Judge Dr. Lemberg (along with the two Associate Justices Dr. Bathe and Dr. Lachs) then proceeded, "I now sign the verdict and I ask to clerk to do the same and read the

\footnotetext{
${ }^{8}$ Eric Bogosian, Operation Nemesis: The Assassination Plot that Avenged the Armenian Genocide (New York: Little, Brown, and Company, 2015), 44.

${ }^{9}$ Henry Morgenthau. Ambassador Morgenthau's Story: A Personal Account of the Armenian Genocide (Ithaca: Cornell University Press, 2008). This reference has been republished numerous times by various publishers and available online as well.

${ }^{10}$ For a full translated record of the court proceedings, together with supplementary materials see Vartkes Yeghiayan, The Case of Soghomon Tehlirian, 2nd ed. (Glendale: Center for Armenian Remebrance, 2006), especially "First Day of Trial" (3-121), "Second Day of Trial" (122-179), and "Verdict" (180).
} 
verdict out loud...The defendant is acquitted at the expense of the state treasury...In accordance with the decision of the jury, the defendant is not guilty of the punishable act with which he has been charged...The order of imprisonment as regards the defendant is hereby annulled."11

\section{What Lemkin (and Others) Did Not Know or Did Not Follow}

To be sure, Lemkin saw, internalized, and interpreted in both Tehlirian's act and subsequent acquittal - and Schwartzbard as well-as he would evolve it, his rationale for an international law against genocide. What he did not know or did not follow were Tehlirian's marriage to his wife Anahit, his fathering two sons, his move back to Serbia where he had lived before, his later move to Belgium with his family, and, finally, his move to San Francisco, CA, in 1945, and where he would later die of a brain tumor in 1960, one year after Lemkin.

In a somewhat startling and disturbing article entitled "My conversation with the son of Soghomon Tehlirian, the man who assassinated the organizer of the Armenian genocide" in the British newspaper The Independent on 20 June 2016, British writer, journalist and Middle East specialist Robert Fisk (b. 1946) wrote:

The family story is both gruesome and tragic and Soghomon Tehlirian's younger son has changed his family name to distance himself from history - and from the Turks who still regard his father as the world's most famous 'terrorist.'

'Later, I found out that he had also killed an Armenian Quizling in Istanbul who was spying for the Turks during the genocide.'

Indeed, in 1920, Tehlirian assassinated Hartyun Mkrtchian, who had helped Talaat round up the initial Armenian clergymen, journalists and lawyers for exile and death in April 1915.

Popular Armenian history would have it that Tehlirian's entire family - his father, mother, sisters, and all three brothers - were murdered in front of him during the genocide. This is untrue. Soghomon Tehlirian was not in Armenia at the time.

He was in Serbia, having moved there quite by chance on the very day in June 1914 that Gavrillo Princip shot the Archduke Ferdinand in Sarajevo, setting off World War I.

'My father never had a sister,' his son says.' He and two of his brothers were in Serbia. It was his mother-my grandmother-who was killed in the genocide, along with his older brother Vasken, who would have been my uncle and who would have been a medical student in Beirut. ${ }^{\prime 2}$

What Lemkin and others did not know until relatively recently was the singularly important fact that Tehlirian had already joined "Operation Nemesis" earlier in 1920 and was very much involved in the process of assassinations of those responsible for the Armenian Genocide. His assassination of the traitorous Armenian Hartyun Mkrtchian took place in Constantinople that same year. "Operation Nemesis", as is now more fully known, was a campaign of the Armenian Revolutionary Federation (ARF), played a significant part in the fund-raising efforts in the United States for Tehlirian's trial, and was also responsible for the assassinations of Fatali Khan Khoyski (1875-1920; June 19, 1920), Bibud Khan Jivanshir (1877-1921; July 18, 1921), Said Halim Pasha (18751921; December 5, 1921), Behaeddin Shakir (1874-1922; April 17, 1922), Djemal Azmi (? -1922; April 17, 1922), Enver Pasha (1881-1922; August 4, 1922), Djemal Pasha (1872-1922; July 21, 1922), as well

\footnotetext{
${ }^{11}$ Yeghiyan, The Case of Soghomon Tehlirian, 180.

${ }^{12}$ One of the enduring myths of Tehlirian's survival and repeated in any number of online biographical accounts was that he was in the desert with his mother who protected him with her body from the bullets as they both fell to the ground.
} 
as the Armenian traitor Vahe Ihssan (? -1920; March 27, 1920)..$^{13}$

\section{The Complicated Case of Sholem-Shmuel Schwartzbard}

Equally so, we must assume that Lemkin's knowledge of Scwartzbard's assassination and subsequent trial and acquittal as reported in those same multi-language newspapers during and immediately following his student days were also reported in the broadest of brushstrokes and offered somewhat hyper-dramatic accounts as was the norm in journalistic reporting in the $18^{\text {th }}$, $19^{\text {th }}$, and early $20^{\text {th }}$ centuries.

However, and significantly, at least publicly, Schwartzbard was not perceived to be a naïve victim who chose to take matters into his own hands, but, rather, an already-known anarchist who had served in both the French Foreign Legion and the Soviet military as well as an accomplished Yiddish poet. ${ }^{14}$ Controversy has continued to surround his deed as to whether it was, in fact, a solo act of reprisal in defense of his victimized Jewish people by Ukrainian pogromchiks or part of an overall conspiracy initiated and organized by the Soviets who regarded Symon Petliura (1879-1926) as a serious threat to their overall political control. ${ }^{15}$ Additionally, and subsequently, the controversy is further fueled by the ongoing debate whether Petliura was, indeed, powerful enough to restrain the antisemitic troops under his command and direction ${ }^{16}$ and the fact that he remains something of a heroic figure in the overall story of Ukrainian nationalism and the desire for total political nation-state independence on the part of the Ukrainian people. ${ }^{17}$

What was known then is the following: Schwartzbard was born August 18, 1886 in Izmail, Bessarabia, and grew up in the town of Balta, approximately thirty miles away. By age seventeen, during his apprenticeship to a watchmaker, he became fascinated with and embraced socialism as a political philosophy. Two years later, 1905, he would spend a brief stint' in prison during the early revolutionary period. After his release, he would move to Austria-Hungary and now saw himself as an anarchist. By 1910, now age twenty-three, he relocated himself to Paris, joined the French Foreign Legion, was wounded in battle, awarded the Croix de Guerre and was demobilized in 1917. Moving back to Russia, he resumed his revolutionary-anarchist activities. During that same period, 1917-1919, at least fourteen members of his own family, including his own parents, were murdered by anti-Semitic progromchiks in the Ukraine under the overall leadership of Symon Petliura. ${ }^{18}$ By 1920, he was back in Paris and disillusioned with the progress of Russian revolutionary activities and its consistent anti-Semitism.

${ }^{13}$ For a more carefully rounded portrait of "Operation Nemesis" and those involved, see both Bogosian, Operation Nemesis; and Marian Mesbrobian MacCurdy, Sacred Justice: The Voices and Legacy of the Armenian Operation Nemesis (New Brunswick and London: Transaction Publishers, 2015). Bogosian is a well-known actor, playwright, and novelist and his text is presented in narrative form but with solid reference materials throughout. MacCurdy is a retired professor from Ithaca College, NY, and her text is both a personal story and an academic one, including family photographs as well.

${ }^{14}$ Somewhat eerily prescient, Yiddish writer Dovid Bergelson (1884-1952), murdered in the infamous Soviet "Night of the Murdered Poets" (12-13 August 1952), would publish a short story in 1923 entitled "Among Refugees," but one where the anonymous "hero" not only does not perform his deed but commits suicide as well. See his The Shadows of Berlin: The Berlin Stories of Dovid Bergelson, trans. Joachim Neugroschel (San Francisco: City Lights Books, 2005), 21-43. See, also, Anna Schur, "Shades of Justice: The Trial of Sholom Schwartzbard and Dovid Bergelson's 'Among Refugees'," Law $\mathcal{E}$ Literature 19, no. 1 (2007), 15-43 for a solid analysis of both.

${ }^{15}$ See Felix and Miyoko Imonti, Violent Justice: How Three Assassins Fought to Free Europe's Jews (Amherst: Prometheus Books, 1994), especially pages 95-104, and how Schwartzbard's attorneys fought hard to disabuse the jury of any notions of such a conspiracy.

${ }^{16}$ See, for example, the important "debate" vis-à-vis Taras Hunczak, "A Reappraisal of Symon Petliura and UkrainianJewish Relations, 1917-1921," Jewish Social Studies 31, no. 3 (1969), 163-183; and Zosa Szajkowski, "A Reappraisal of Symon Petliura and Ukrainian-Jewish Relations, 1917-1921: A Rebuttal," Jewish Social Studies, 31, no. 3 (1969), 184-213; Taras Hunczak and Zosa Szajkowski, "Communications," Jewish Social Studies 32, no. 3 (1970), 246-263. The controversy surrounding Petliura is to what degree he was able to exercise his authority over his troops, including those who's overt anti-Semitism was in evidence.

${ }^{17}$ On 16 October 2017, for example, the Jewish Telegraphic Agency (JTA) reported “Ukraine honors nationalist leader blamed for Jewish pogroms" with the unveiling of a statue of Petliura in the city of Vinnitsa.

${ }^{18}$ Complicating the overall picture of Petliura is the fact that there remains no evidence of anti-Semitism on his part, and at least one directive, dated 26 August 1919, declaring his opposition to violent acts against Jews. Papers have supposedly recently been found that Petliura also may have supported a call for the founding of a Jewish state. 
Petliura, now in exile himself after his failed attempt at independence, would first flee to Warsaw, Poland, then to Budapest and Vienna, Austro-Hungary, then to Geneva, Switzerland, finally arriving in Paris in 1924.

On May 25, 1926, Schwartzbard shot Petliura seven times at close range, chose not to flee, and when seized by the police reportedly said, "I have killed a great assassin." ${ }^{19}$ Schwartzbard's trial began on October 18, 1927, having pled "Not Guilty" to all charges; his defense team was led by Henri Torres (1891-1986), the flamboyant trial lawyer and politician and only thirty-six years old at the time of the trial. ${ }^{20}$ (Formerly both a Communist and journalist who fought for the French in World War I, Torres fled to South America and the United States after the Nazi invasion in 1940, returning after the Second World War, and was elected to the French Parliament as well as becoming the Vice President of the High Court of Justice.) Eight days after its beginning-October 26, 1927-after jury deliberations lasting a mere thirty-five minutes, Schwartzbard was acquitted with loud congratulations and cries of "Long live France!" erupting in the courtroom. Afterwards, he would attempt to relocate to British-held Palestine but was denied entry, would later die in Cape Town, South Africa, after contracting an illness. In 1967, his remains were reinterred in Israel. ${ }^{21}$

At its successful conclusion, on par with Torres' strategy, the trial itself was more about the murders of Jews during the pogroms rather than about Petliura's death. (The trial of Tehlirian, too, could equally thus be assessed as employing the same tactic, i.e., the crime of the Armenian Genocide by the Turks rather than the murder of a single individual. ${ }^{22}$ Jews saw it as a vindication of their plight in Eastern Europe; Ukrainians saw it far more as condemnation of themselves. The French press itself, however, was divided in its own assessments, some positively supportive others highly critical and negative.

\section{Two Post-Event Assessments}

Attempting a "psychological read" of Schwartzbard, Felix and Miyoko Imonti in their book Violent Justice: How Three Assassins Fought to Free Europe's Jews, and not unlike Tehlirian who himself was not without psychic difficulties, portray him as an "alienated outsider:"

If he was a hero to these survivors of the madness, he was something less heroic to others. As always, Schwartzbard was an outcast from the mainstream. He was a blend of unresolved contradictions that provided enough friction to alienate the majority...

As a young revolutionary in the Spark movement, he had aroused the hostility of the others who saw his clinging to Judaism as a rejection of Marxism. As an orthodox Jew, he had been denied by Jews, who considered his propensity for violence to be contrary to the principles of the faith.

His triumph in court did not end the alienation. In his memoirs, Schwartzbard denounced his friends for failing his cause..$^{23}$

\footnotetext{
${ }^{19}$ As reported in "France: Petliura Trial," Time Magazine, November 7, 1927, accessed January 16, 2018, http://content.time.com.

${ }^{20}$ Whether or not Schwartzbard did so at the behest of his attorney Torres, consistently, he lied about his background, age, place of birth, previous imprisonments, and even his prior military service. His command of the French language, despite his past, was poor, and he asked that questions be repeated several times. He made it a point, however, to wear his Croix de Guerre, emblematic of his service to France in World War I, throughout his trial.

${ }^{21}$ Many of Schwartzbard's papers are today housed in the YIVO Institute for Jewish Research, Center for Jewish History, New York, NY, and consists of correspondence, newspaper clippings, manuscripts, and notes relating to the trial and later. Important as well is the book by David Engel, The Assassination of Symon Petliura and the Trial of Sholem Schwarzbard, 1926-1927: A Selection of Documents (Göttingen: Vandenhoeck \& Ruprecht, 2016).

${ }^{22}$ The Israeli prosecution team likewise would make the Adolf Eichmann trial in Israel in 1961, ultimately more about the Holocaust against the Jewish people than about a singular culprit.

${ }^{23}$ Felix and Miyoko Imonti, Violent Justice: How Three Assassins Fought to Free Europe's Jews (Amherst: Prometheus Books, 1994), 106.
} 
Schwartzbard, with or without the collusion of the Soviets, and with or without the support of the Jews of the Ukraine and elsewhere at the time of his assassination, remains somewhat shrouded in mystery as to his overall psychological and religious, not to mention political, motivations. ${ }^{24}$

As to Petliura, Saul S. Friedman in his book Pogromchik; The Assassination of Simon Petliura arrives at the following conclusions:

1. Simon Petliura was Chief of State, Ataman-in-Chief, with real power to act when he so desired.

2. Units of the Ukrainian Army directly under his supervision (the Clans of Death) committed numerous atrocities.

3. Insurgents depended upon Petliura for financial support and war material and committed pogroms in his name.

4. Official organs of the Ukrainian War Office, the Government Printing Works, and the Information Bureau of the National Army incited pogroms by vicious anti-Semitic propaganda.

5. Petliura reneged on promises made to Jews as early as November 1917, that effective inquiries would be made into pogroms.

6. There is good reason to believe that Petliura may have ordered pogroms in Proskurov and Zhitomir in the early months of 1919, and that the Holovni Ataman was in the immediate vicinity of these towns when pogroms were raging.

7. Petliura's famous orders of August 26 and 27, 1919, forbidding pogroms, were issued eight months too late, at a time when the Holovni Ataman had no real power.

8. What funds were authorized for the relief of pogrom victims were a trifle compared with how much was needed and how much had been stolen from the Jews.

9. Petliura's Jewish Ministry was a mere façade and his last minister, Pinchas Krasny, a sycophant, was totally out of touch with his community, and reviled by Jews.

10. Even from afar, in Paris, Petlliura conducted a program, which infuriated Jews. ${ }^{25}$

Given the newly discovered information noted regarding Petliura, his attitudes and responses towards the Jews of the Ukraine remains further complicated, and thus makes Schwartzbard's deed all that much more complicated as well.

\section{Conclusions}

As noted previously, for Lemkin, the trials and acquittals of both Tehlirian and Schwartzbardas well as the publicly- and, at times, overly-dramatic journalistic coverage-provided the underpinnings to his evolving concept of the need for an international convention forbidding genocide. Were more knowledge about both men and their associations available to him, it is conceivable that he might not have been able to make the virtual use of them as he records in his autobiography. Further, ever the pragmatist when it came to getting the necessary votes in 1948 for the passage of the Genocide Convention, the two trials and acquittals furthered his initial thinking about how to proceed. Having done so, there was little additional need to make use of these two cases - or any other political assassination as such - and seemingly little additional value after that.

Sometimes history itself presents the necessary opportunities, which move processes forward. Other times, motivated and energized individuals are able to seize the moment and make fuller use of events than they themselves were originally intended and understood. The complicated cases of Soghomon Tehlirian and Samuel Schwartzbard are but two and not the only two whereby such factors intersect, and the upshot become a positive result even if built upon shaky and dubious foundations.

\footnotetext{
${ }^{24}$ An interesting attempt at fathoming out his motivations and story is that of Kelly Johnson's doctoral dissertation. Kelly Johnson, "Sholem Schwarzbard: Biography of a Jewish Assassin" (PhD diss., Harvard University, 2012), accessed October 18, 2018, http://nrs.harvard.edu/urn-3:HUL.InstRepos:9830349.

${ }^{25}$ Saul S. Friedman, Pogromchik: The Assassination of Simon Petliura (New York: Hart Publishing Company, 1976), 372-374.
} 


\section{Bibliography}

Bard, Mitchell G. 48 Hours of Kristallnacht: Night of Destruction/Dawn of the Holocaust: An Oral History. Guilford: The Lyons Press, 2008.

Bergelson, Dovid. The Shadows of Berlin: The Berlin Stories of Dovid Bergelson. Translated by Joachim Neugroschel. San Francisco: City Lights Books, 2005.

Bogosian, Eric. Operation Nemesis: The Assassination Plot that Avenged the Armenian Genocide. New York: Little, Brown and Company, 2015.

Broner, Peter. Night of the Broken Glass- A Novel. New York: Station Hill, 1991.

Engel, David. The Assassination of Symon Petliurs and the Trial of Sholem Schwarzbard, 19261927: A Selection of Documents. Göttingen: Vanderhoeck \& Ruprecht, 2016. https://doi. org/10.13109/9783666310270

"France: Petliura Trial." Time Magazine, November 7, 1927. Accessed January 16, 2018. http:// content.time.com.

Friedman, Saul S. Pogromchik: The Assassination of Simon Petliura. New York: Hart Publishing Company, 1976.

Gerhardt, Uta and Thomas Karlauf, eds. The Night of Broken Glass: Eyewitness Accounts of Kristallnacht. Cambridge, UK and Malden: Polity, 2012.

Gilbert, Martin. Kristallnacht: Prelude to Destruction. New York and London: Harper, 2006.

Heiden, Konrad. The New Inquisition. Translated by Heinz Norden. New York: The Starling Press, 1939.

Hunczak, Tara. "A Reappraisal of Symon Petliura and Ukrainian-Jewish Relations, 1917-1921." Jewish Social Studies 31, no. 3 (1960), 163-1983.

Hunczak, Taras and Zosa Szajkowski. "Communications." Jewish Social Studies 32, no. 3 (1970), 246-263.

Imonti, Felix and Miyoko Imonti. Violent Justice: How Three Assassins Fought to Free Europe's Jews. Amherst: Prometheus Books, 1994.

Johnson, Kelly. "Sholem Schwarzbard: Biography of a Jewish Assassin." PhD Diss., Harvard University, 2012. Accessed October 18, 2018. http://urs.hardvard.edu.urn-3:HUL. InstRepos:9830349.

Kirsch, Jonathan. The Short, Strange Life of Herschel Grynszpan: A Boy Avenger, a Nazi Diplomat and a Murder in Paris. New York: Liveright, 2013.

Kochan, Lionel. Pogrom: November 18, 1938. London: Andre Deutsch, 1973.

Lemkin, Raphaël. “Totally Unofficial Man.” In Pioneers of Genocide Studies, edited by Samuel Totten and Steven Leonard Jacobs, 365-399. New Brunswick and London: Transaction Publishers, 2000.

---------. Totally Unofficial: The Autobiography of Raphaël Lemkin. Edited by Donna-Lee Frieze. New Haven and London: Yale University Press, 2013.

Levitt, Ruth, ed. Pogrom 1938: Prelude to the Holocaust; Testimonies from 'Kristallnacht'. London: Souvenir Press, 2015.

Loeffler, James. "Becoming Cleopatra: the forgotten Zionism of Raphaël Lemkin." Journal of Genocide Research 19, no. 3 (2017), 340-360. https://doi.org/10.1080/14623528.2017.1349645

MacCurdy, Marian Mesrobian. Sacred Justice: The Voices and Legacy of the Armenian Operation Nemesis. New Brunswick and London: Transaction Publishers, 2015.

Marino, Andy. Herschel: The Boy Who Started World War II. Boston and London: Faber and Faber, 1995.

Mazzenga, Maria, ed. American Religious Responses to Kristallnacht. New York: Palgrave Macmillan, 2009. https://doi.org/10.1057/9780230623309

McCullough, Colin and Nathan Wilson, eds. Violence, Memory and History: Western Perceptions of Kristallnacht. London and New York: Routledge, 2015.

Morgenthau, Henry. Ambassador Morgenthau's Story: A Personal Account of the Armenian Genocide. Ithaca: Cornell University Press, 2008.

Pehle, Walter, H., ed. November 1938: From 'Kristallnacht' to Genocide. New York and Oxford: Berg, 1991. 
Reed, Anthony and David Fisher. Kristallnacht: The Nazi Night of Terror. New York: Random House, 1989.

Schur, Anna. "Shades of Justice: The Trial of Sholom Schwartzbard and Dovid Bergelson's 'Among Refugees'." Law \& Literature 19, no. 1 (2007), 15-43. https://doi.org/10.1525/lal.2007.19.1.15

Schwab, Gerald. The Day the Holocaust Began: The Odyssey of Herschel Grynszpan. New York and London: Prager, 1990.

Stanislawski, Michael. Autobiographical Jews: Essays in Jewish Self-Fashioning. Seattle and London: University of Washington Press, 2004.

Steinweis, Alan E. Kristallnacht 1938. Cambridge, MA and London: Harvard University Press, 2009. https://doi.org/10.4159/9780674054653

Szajkowski, Zosa. "A Reappraisal of Symon Petliura and Ukrainian-Jewish Relations: A Rebuttal." Jewish Social Studies 31, no. 3 (1970), 184-213.

Warburg, G. Six Years of Hitler: The Jews Under the Nazi Regime. London: George Allen \& Unwin, 1939.

Yeghiayan, Vartkes. The Case of Soghomon Tehlirian, 2nd ed. Glendale: Center for Armenian Remembrance, 2006. 